\title{
Structure and crustal shortening of the Subhimalayan fold and thrust belt, western Arunachal Pradesh, NE India
}

\author{
Thomas K Kelty†*, An Yin‡, and CS Dubey§ \\ † Department of Geological Sciences, California State University, Long Beach, California 90840-3902, USA \\ $¥$ Department of Earth and Space Sciences and Institute of Geophysics and Planetary Physics, University of California, Los Angeles, \\ CA 90095-1567, USA \\ § Department of Geology, University of Delhi, Delhi 110007, INDIA
}

*To whom correspondence should be addressed.E-mail: tkelty@csulb.edu

The Subhimalayan fold and thrust belt of western Arunachal Pradesh (AP) includes Miocene and younger sedimentary rocks that comprise northward dipping thrust sheets, structurally below the Main Boundary Thrust (MBT) and above the Main Frontal Thrust (MFT). Balanced cross sections are constructed at various locations along a $100-\mathrm{km}$ segment of the AP Subhimalayan fold and thrust belt. Comparison of these sections reveals structural configurations that are remarkably consistent perpendicular and parallel to the fold and thrust belt. Three regionally significant faults are developed from north to south and are the: (1) MBT, (2) Tipi Thrust and (3) MFT. These faults are subparallel and strike approximately E-W for $200 \mathrm{~km}$ from the eastern Bhutan/India border to the Dikrang River, where the strike changes to $\mathrm{N} 50^{\circ} \mathrm{E}$ and continues NE to eastern syntaxsis.

There are four lithostratigraphic units in the AP Subhimalayan fold and thrust belt, between the MBT and MFT. From oldest to youngest, the consist of the Kimi, Dafla, Subansiri, and Kimin Formations. The Dafla and Subansiri Formations are equivalent to the Middle Siwalik (Kumar 1997). The Kimin and Kimi Formations are equivalent to the Upper and Lower Siwalik, respectively (Kumar 1997). There are no early Miocene lithostratigraphic equivalents in AP to the Murree Formation, Pakistan, the Kasauli and Dagshai Formations, northern India, and the Dumri Fm, Nepal (Kumar 1997).

Within the AP Subhimalayan zone the structures can be lumped into two tectonostratigraphic units: (1) the MFT-Tipi Thrust unit and (2) the MBT-Tipi Thrust unit. The structures of the fold and thrust belt between the MFT and Tipi Thrust in most locations consists of a northerly dipping $\left(10^{\circ}\right.$ to $\left.30^{\circ}\right)$ monocline consisting of the Subansiri and Kimin Formations. This part of the fold and thrust belt is interpreted to be the hanging wall flat above the MFT. There are also large folds developed between the Tipi Thrust and MFT. For example, in the Dikrang river valley, a 20-km-long plunging anticline is interpreted to be a fault bend fold above a ramp in the MFT. The tectonostratigraphic unit bounded by the MBT and Tipi Thrust consists exclusively of Dafla Formation that dips northward between $20^{\circ}$ to $60^{\circ}$. The Subansiri and Kimin Formations have not been observed in the hanging wall of the Tipi Thrust in AP. No ramp anticlines are developed on top of the Tipi Thrust, which cuts upsection through approximately $4.5 \mathrm{~km}$ of the Neogene sedimentary rocks. The Tipi Thrust is interpreted to flatten into a decollement that is regionally extensive and located at the base-Neogene unconformity. The decollement is developed in the AP Subhimalayan zone over a distance of at least $300 \mathrm{~km}$. There is evidence of structurally analogous fault to the Tipi Thrust described in the Subhimalayan fold and thrust belt of Nepal (1000 km to the west). In Nepal, several thrusts place Lower and Middle Siwalik on top of Upper Siwalik. DeCelles et al. (2001) identified a thrust between the MBT and MFT in western Nepal. In central Nepal, Lave and Avouac (2000) describe the Main Dun
Thrust. In eastern Nepal, Schelling and Arita (1991) document the Dabmai Thrust. All of these thrust faults are structurally analogous to the Tipi Thrust. It is not being proposed here that the Tipi fault is traceable for $1000 \mathrm{~km}$ to Nepal. In fact it is uncertain if an equivalent to the Tipi Thrust has been identified in the Subhimalayan zone of Bhutan. However, it is likely that the same stratigraphically controlled, regional decollement exists at the base of the Siwalik or top of pre-Tertiary basement in Nepal and AP. The depth to the detachment in both Nepal and western part of AP is approximately $5 \mathrm{~km}$.

The restored balanced cross sections are used to estimate the amount of shortening within the AP Subhimalayan fold and thrust belt. The regional dip and depth of basement for these cross sections is based on seismic sections and aeromagnetic data interpreted by Kumar (1997). The minimum shortening between the MFT and Tipi Thrust is about $6 \mathrm{~km}$. The minimum shortening between the MBT and Tipi Thrust is also approximately $6 \mathrm{~km}$. Thus, the total minimum shortening across the Subhimalayan zone is approximately $12 \mathrm{~km}$. This interpretation includes a dramatic four-fold stratigraphic thickening of the Dafla Formation across the Tipi Thrust. Structural thickening caused by fault imbrication is an alternative interpretation to an increase in stratigraphic thickness of the Dafla Formation. This imbricate system has the geometry of a leading imbricate fan. The alternative structural interpretation increases the estimate of shortening to maximum of $30 \mathrm{~km}$ between the MBT and MFT.

Because the Kimin Formation is truncated by the Tipi Thrust and MFT, deformation must have occurred in the Subhimalayan fold and thrust belt since 1.5 Ma. Given the minimum estimate of shortening (stratigraphic thickening) of $12 \mathrm{~km}$, the minimum-shortening rate is $8 \mathrm{~mm} / \mathrm{yr}$. If the Dafla Formation has been structurally thickened the shortening rate could be as high as $20 \mathrm{~mm} / \mathrm{yr}$. Powers et al. (1998) determined shortening rates of $6-16 \mathrm{~mm} / \mathrm{yr}$ for the Subhimalayan zone in NW India.

\section{References}

DeCelles P, DM Robinson, J Quade, TP Ojha, CN Garzione, P Copeland and BN Upreti. 2001. Stratigraphy, structure, and tectonic evolution of the Himalayan fold-thrust belt in western Nepal. Tectonics 20(4): 487-509

Kumar G. 1997. Geology of Arunachal Pradesh. Bangalore: Geological Society of India. $217 \mathrm{p}$

Lave J and JP Avouac. 2000. Active fold of fluvial terraces across the Siwaliks Hills, Himalayas of central Nepal. Journal of Geophysical Research 105(B3): 5735-70

Powers PM, RJ Lillie and RS Yeats. 1998. Structure and shortening of the Kangra and Dehra Dun reentrants, Sub-Himalaya, India. Geological Society of America Bulletin 110(8): 1010-27

Schelling D and K Arita. 1991. Thrust tectonics, crustal shortening, and the structure of the far-eastern Nepal Himalaya. Tectonics 10(5): 85162 